\title{
Restoration-as-development? Contesting Aspirational Politics Regarding the Restoration of Wildlife Corridors in the Kilombero Valley, Tanzania
}

\author{
Astrid Matejcek $^{1}$ D . Julia Verne ${ }^{2}$
}

Accepted: 10 April 2021 / Published online: 29 April 2021

(c) The Author(s) 2021

\begin{abstract}
Due to recent land-use change, wildlife migration through the Kilombero Valley has almost come to a standstill. In line with global restoration efforts, the African Wildlife Foundation has thus been given the task of implementing the Restoration Opportunity Assessment Methodology (ROAM), recently developed by IUCN and the World Resources Institute to foster the restoration of wildlife corridors in the area. Designed as a collaborative endeavour, it is in processes such as these that the aspirations of global restoration policies are confronted with specific local contexts. By focusing on specific situations and encounters, especially regarding the participatory aspects of the project, we illustrate how global policy aspirations are appropriated, partly contested and partly played along with, before finally turning into something of an illusion. This way, this article not only questions the more optimistic claims made for 'conservation-as-development', it also argues that a better understanding of the plurality of local aspirations and the ways in which they interact with the project's goals is needed if global policy aspirations are to be realized more successfully.
\end{abstract}

Keywords Conservation-as-development · Rural aspirations · Wildlife corridors · Forest landscape restoration · Kilombero Valley

\section{Résumé}

Suite au récent changement d'utilisation des terres, la migration de la faune à travers la vallée de Kilombero s'est quasiment arrêtée. Conformément aux efforts de restauration à l'échelle internationale, la Fondation African Wildlife s'est ainsi vu confier

Astrid Matejcek

astrid.matejcek@uni-bonn.de

Julia Verne

julia.verne@uni-mainz.de

1 Rheinische Friedrich-Wilhelms University, Bonn, Germany

2 Johannes Gutenberg University in Mainz, Mainz, Germany 
la tâche d'appliquer la méthodologie d'évaluation des opportunités de restauration (MEOR), récemment développée par l'UICN et le World Resources Institute pour favoriser la restauration des couloirs de la faune dans la région. C'est dans ce type de processus, conçu comme une initiative collaborative, que les ambitions des politiques de restauration à l'échelle internationale sont confrontées à la spécificité des contextes locaux. En nous penchant sur des situations et des rencontres spécifiques, notamment sur l'aspect participatif du projet, nous illustrons la façon dont les acteurs s'approprient les ambitions politiques internationales, d'une part en s'y opposant et d'autre part en se soumettant à leurs règles, jusqu'à ce que ces ambitions finissent par se transformer en une sorte d'illusion. Ainsi, non content de remettre en question les affirmations plus optimistes en faveur de la "conservation pour le développement", cet article soutient également la théorie selon laquelle il faut une meilleure compréhension de la pluralité des aspirations locales et de la manière dont elles interagissent avec les objectifs du projet pour que les ambitions politiques internationales puissent être réalisées avec plus de succès.

\section{Introduction}

'Connecting People with Nature - African Wildlife Foundation' runs the slogan on the T-shirt one of the AWF officers was wearing on a field visit in the Kilombero Valley, south-central Tanzania. On that day, we accompanied the NGO team on its inspection of tree nurseries to monitor the growth of young plants and the way villagers look after them. These seedlings will be the most important component in the restoration of wildlife corridors, which lead through the floodplain of the Kilombero River, nestled between the Udzungwa Mountains to the northwest and the Mahenge Highlands to the southeast.

In the recent past, the valley has evolved into a scene of far-reaching change due to the expansion of agricultural land and an increase in cattle-keeping at the expense of the forests (Dinesen 2016). Both the Udzungwa Mountains National Park (UMNP) and the Kilombero Nature Reserve (KNR), as well as several other reserves, are clearly suffering from the decimation of wildlife numbers as an effect of illegal deforestation, fires, the expansion of agricultural land and poaching (Nindi et al. 2014, p. 176). Rapid human population growth and the increased consumption of forest resources have made it more and more difficult to maintain park boundaries in the region (Baldus et al. 2007; Dinesen 2016).

Wildlife corridors are supposed to form a crucial connection between these different spaces of conservation, as they should permit wildlife, particularly large game, to pass through settlements, fields and forests used by humans (Newmark 2008). However, in the recent past, the mobility of species has come to a standstill due to increasing degradation and habitat fragmentation. Rice fields and the large numbers of cattle being herded in these areas are making it increasingly difficult to identify the spaces designated for the corridors. Moreover, the long history of conflict between humans and wildlife is highlighting the mutual risks that may accompany species migration through human settlements, resulting in the local population making even fewer efforts to maintain the corridors (Bamford 
et al. 2011). Nevertheless, to conserve the species and their ecosystems outside protected areas, the migration routes to water and refuges for reproduction and genetic exchange remain indispensable (Newmark 2008), turning degraded and deforested wildlife corridors into a prime target of global reforestation efforts. Indeed, it is the aspiration to restore forest landscapes, as formulated and expressed in the context of the so-called Bonn Challenge, that has led to the AWF implementing the Restoration Opportunity Assessment Methodology (ROAM) developed by the International Union for Conservation of Nature (IUCN) and the World Resources Institute (WRI) in order to enhance the restoration of wildlife corridors in the Kilombero Valley.

As Huijsmans et al. have recently observed, the field of development is characterized by "deeply aspirational landscapes" (Huijsmans et al. 2021, p. 8), as "planning for and bringing about desired forms of change is key to development practice" (Huijsmans et al. 2021, p. 2). But whereas the "aspirational politics" (Finnemore and Jurkovich 2020) of forest restoration seem to have no problems in persuading development practitioners to commit to their realization, the often rather disappointing results of such projects raise questions about how such aspirations are seen at the local level, and to what extent, if any, they may be aligned with potentially different aspirations among the local communities in which the projects are to be implemented.

In line with other Integrated Conservation and Development Projects (ICDPs) which aim to enable conservation while striving for development goals at the same time (Vaccaro et al. 2013), the active restoration of spaces for animal migration by the AWF is characterized by a participatory project design and the vision of co-creating spaces of mutual benefit for animals and humans by working in close collaboration with the villages along the corridors. As with other development projects, notions of empowerment, capacity-building and the enhanced productivity of the land are used as tools to galvanize local support for the restoration of wildlife corridors (Finnemore and Jurkovich 2020), thus dominating the project's implementation and evaluation as a result. However, as this in-depth ethnographic study of the performance of this project in three different stretches of the corridor reveals, these goals are complicated by the particular nature of the corridors, as they are situated in a setting that brings farmers, pastoralists and wildlife into conflict with one another. Thus, in extending the focus to wildlife corridors as a crucial yet often neglected component of large-scale conservation, we wish to highlight the complex local dynamics that may be triggered by such restoration efforts in such highly contested spaces. By focusing on specific situations and encounters, especially during the participatory elements of the project, we are able to show how global policy aspirations are refined and appropriated, challenged or played along with, by the diverse local actors, before finally turning into something of an illusion. Against this background, this article not only questions more optimistic claims for 'restoration-as-development', it also argues that a better understanding of the plurality of local aspirations and the ways in which they interact with the project goals is needed if global policy aspirations are to be realized more successfully. 


\section{Aspirations to Restore Landscapes: Conservation as a Development Challenge}

Conservation efforts in the Global South have a chequered history in respect of their relationship with development. Since colonial times, the underlying motivations behind wildlife conservation and associated park foundations have largely remained persistent. Apart from the protection of species and further research to improve understanding of their behaviour and needs, revenue generation has also long been regarded as a major incentive for the establishment of conservation areas. Whereas the focus was initially on hunting tourism, the emphasis was soon placed on wildlife safaris as economically beneficial activities. However, in the early agendas of foreign and international organizations, such as the Society for the Protection of Fauna of the Empire (SPFE), based in London, and the Frankfurt Zoological Society (FZS) — accompanying, for example, the establishment of the Serengeti National Park in Tanzania-the role of local land use was not only neglected but entirely lacking (Goldman 2009, p. 342). On the one hand, this has resulted in one-sided structures of profiteering from wildlife conservation measures. On the other hand, if they were noticed at all, local livelihoods were seen as acting in opposition to conservation efforts and thus needed to be excluded and restricted by international conservation organizations, tourism industries and governments (Neumann 1995; Benjaminsen et al. 2013).

Against this background, political ecologists in particular opened up the debate on 'conservation-against-development' (Folke 2006). Nature conservation as a political tool for cultural universalization and territorial homogenization was taken up by different scholars to demonstrate the problematic social consequences of 'fortress conservation' (Brockington 2002). In contrast, 'conservation-fordevelopment' (Folke 2006) follows the idea that the right to development should constitute an integral part of conservation policies; accordingly, it has come to characterize a large number of initiatives since the 1970s (Vaccaro et al. 2013, p. 257). In this vein, the aim of Integrated Conservation and Development Projects (ICDPs) is the co-management of nature in collaboration local communities (Vaccaro et al. 2013). As others have pointed out, the devolution of power and access to natural areas promise a win-win situation when it comes to tackling the illegal wildlife trade, integrating rural development, ensuring livelihoods and increasing local empowerment (Newmark and Hough 2000; Hughes and Flintan 2001).

Nevertheless, many projects that have been developed and implemented under the umbrella of ICDPs have been criticized for trading off development and conservation, instead of integrating or balancing the two. As Büscher and Arsel (2012) have highlighted, development and conservation are often still seen as competing for funding, space, time and outcomes (see also Goldman et al. 2010). Yet, ICDPs remain the figurehead for government and non-government actors in global conservation efforts.

In Tanzania, the devolution of power and the regulation of protected areas by locals never occurred to the extent promised. Despite the large amounts of 
international funding that accompanied this new approach, little seems to have changed with regard to either development or conservation. The reasons for this are numerous, but the major problems seem to lie in a lack of transparency and decentralization, excessive bureaucratic constraints and, ironically, the lack of any involvement by donors in the policies being implemented, even though they pushed the participatory agenda in the first place (Goldman 2003; Nelson and Agrawal 2008; Benjaminsen et al. 2013).

\section{Restoration as a Global Policy Goal}

Meanwhile, it appears as if the task of beating conservation and development goals at a stroke has become ever more urgent, given the rapidly deteriorating state of the environment. According to global reports, deforestation, habitat loss and species extinction have reached unprecedented levels at unparalleled speed. As a result, the restoration of ecosystems, habitats, migration routes and especially over-exploited landscapes has become a major goal of global political efforts. On the one hand, restoration to rebuild degraded areas is a common practice within protected areas. On the other hand, restoration ecology is still a relatively young field of research, experimentation and practice (Matzek et al. 2017).

The core of restoration ecology has increasingly distanced itself from the idea of replicating historical landscapes that formerly were ideally untouched by humans. Under today's rapidly changing conditions, historical ecosystems often simply no longer appear viable (Higgs et al. 2014; Matzek et al. 2017). Moreover, the stress in restoration is currently undergoing a re-orientation towards functions, services and goods for humans (Higgs et al. 2014). As nature appears to be too slow in keeping pace with planetary change, human support is increasingly considered imperative (Ellis and Ramankutty 2008; Adams 2012; Ellis 2015). As Howell et al. highlight, to establish long-term resilient ecosystems, people are now being considered part of the solution in a 'world of wounds' (Howell et al. 2012, p. 6; Butterfield et al. 2016), further emphasizing the need to think about environmental concerns and human development together. In this regard, political environmentalists, environmental economists and restoration ecologists seem to agree that it is particularly by increasing the productivity of technical ecosystems that environmental concerns can be reconciled with development aims (Büscher and Arsel 2012; Ellis 2015).

It is in this context that restoration has become a future agenda of international environmental policies such as the so-called Bonn Challenge, which aims to defeat climate change, stop deforestation and protect biodiversity while fostering new development opportunities at the same time. In 2011, the German government, the IUCN and later the New York Declaration on Forests set the task of restoring 150 million hectares of degraded areas globally by 2020 and planting 350 million hectares by 2030 (IUCN 2017). The practical implementation of the first milestone is already being recognized as a great success, with 74 committed countries, states or associations, as well as 210 million hectares of land formally designated for restoration (IUCN 2020, p. 11). The African Forest Landscape Restoration Initiative (AFR100), an associated continental sub-goal initiative, aims to restore 100 million hectares of land all over Africa by 2030 
(WRI 2018). So far, Rwanda, Niger and Ethiopia are considered as having taken up a pioneering role in terms of hectares already restored; in 2016, the Tanzanian government also committed itself to this goal.

\section{Creating Landscapes of Multiple Benefits: ROAM}

In the Forest Landscape Restoration (FLR) approach, as recommended by the Bonn Challenge, it is claimed that more losses are generated through inactivity than by investing in restoration. This argument forms the basis for resolving the mismatch between conservation and development initiatives, since according to this perspective, no development project could generate more income than an intact ecosystem (IUCN 2017). Through restoration, local communities are supposed to secure or create goods and services. Thus, in this framework, conservation is not considered to be acting either for or against development: it is development (West 2006).

To give an idea of how 'conservation-as-development' may work and to assist in the identification and prioritization of degraded landscapes for restoration as forest landscapes, the IUCN and the World Resources Institute (WRI) have developed the Restoration Opportunity Assessment Methodology (ROAM). These instructions, as well as the main application of ROAM in the Global South, testify to the increasing interwovenness of international environmentalism with the various logics of development practices (IUCN and WRI 2014; IUCN 2017; IUCN 2018). While leading the reader through an analytical framework that focuses on landscape planning, extensive mapping, modelling and business opportunities, the accompanying handbook says little about how ecological restoration should be conducted on the ground. Instead, ROAM offers participatory, empowering, capacity-building and income-generating mechanisms to restore intensively used landscapes beyond protected areas. The result is supposed to be 'a patchwork or mosaic of different land uses, including, for example agriculture, agroforestry systems and improved fallow systems, ecological corridors, discrete areas of forests and woodlands, and river or lakeside plantings to protect waterways' (IUCN and WRI 2014, p. 16).

In the Kilombero Valley, the local office of the African Wildlife Foundation has been given the task of introducing this approach to the local context. It is in this process, when the 'one-size-fits-all' approach representing global aspirations for restored forest landscapes comes down to earth in specific local contexts that the challenges of such aspirational politics become visible (Finnemore and Jurkovich 2020). As we argue, the project's focus on the restoration of wildlife corridors particularly complicates the motivation and mobilization of the local population to commit to a future as desired by ROAM, as these are situated in a highly conflictual setting of farmers, pastoralists and wildlife. 


\section{Contested Wildlife Corridors in Kilombero Valley}

The Kilombero Valley in the south of Tanzania, one of the largest wetlands in Africa, nestles between the Udzungwa Mountains to the northwest and the Mahenge Highlands to the southeast (see Map 1). A wealth of rivers empty into the Kilombero River, which floods seasonally between November and June because of a bottleneck downstream close to Ifakara, the urban centre of Kilombero District. Correlated with the rainy season, different characteristic ecosystems have evolved, starting in the flooded valley and leading up to the foothills (riverside vegetation, low-lying valley grassland, tall grass, marginal grassland and woodland, combretaceous wooded grassland and miombo woodland). This variety of ecosystems is home to a rich flora and fauna, several species of which are endemic (Dinesen 2016, p. 4).

Today, a number of smaller wildlife management areas and forest reserves adjoin or form part of the valley in the spirit of more recent participatory conservation efforts. Together with the oldest and largest reserves in the region, such as the Selous Game Reserve (including the part recently renamed as Nyerere National Park), Kilombero Nature Reserve, Udzungwa Mountains National Park, Kilombero Valley Game Controlled Area and the Kilombero Valley Floodplain (placed on the list of Wetlands of International Importance, also known as Ramsar sites, by the Convention of Wetlands), these form a patchwork of protected areas. However, the valley has long been known for hosting the largest wildlife populations in Tanzania outside of protected areas. Apart from its wildlife, Kilombero District in Morogoro Region also hosts about half a million people who make their livelihoods through

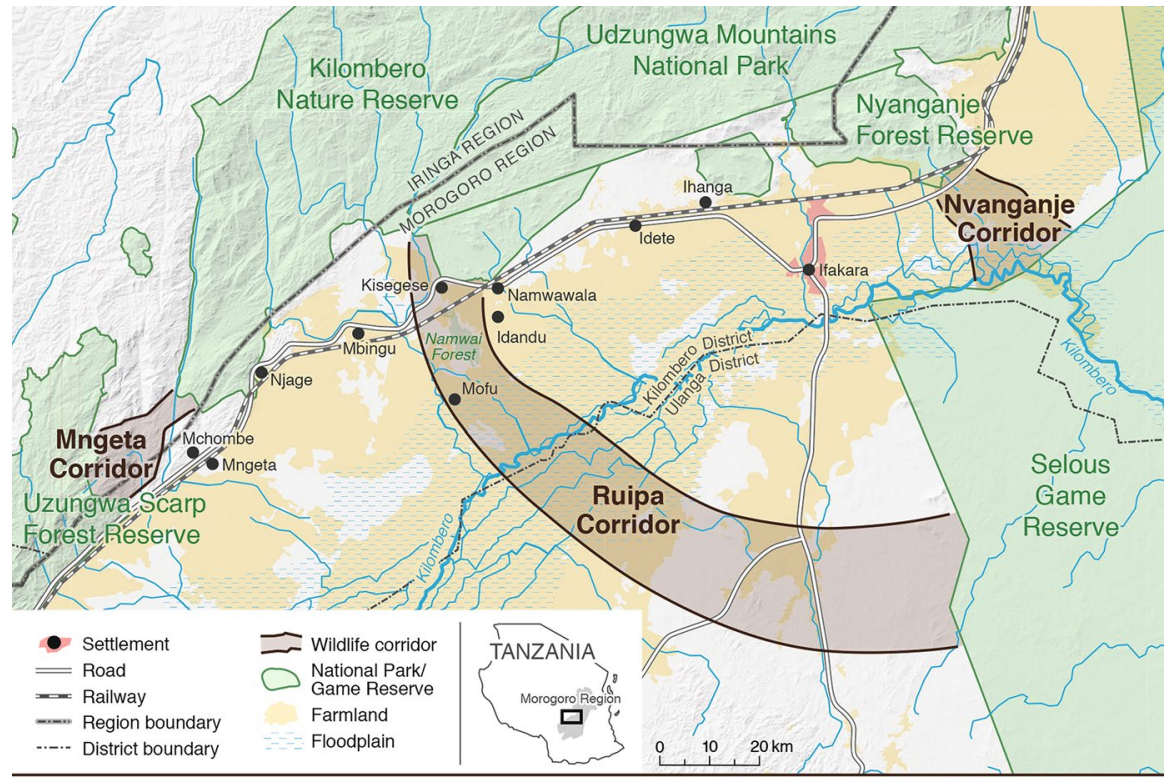

Cartography: Irene Johannsen, Geodata: $\odot$ OpenStreetMap contributors, Made with Natural Earth, GADM, Jarvis et al. (2008), UNEP-WCMC and IUCN (2021), Rovero and Jones (2012), Chen et al. (2015)

Map 1 Kilombero Valley with wildlife corridors 
different activities in the landscape, profiting from fertile soils, readily available water and a favourable climate. To this day, agriculture, with rice and maize as the main crops, remains the prior subsistence activity and source of income in the valley for small- and large-scale farmers (Nindi et al. 2014; Dinesen 2016).

In recent decades, the favourable conditions of the Kilombero Valley have attracted large numbers of migrants from other parts of Tanzania. Since independence, the population has increased tenfold (URT 2013; Nindi et al. 2014, p. 178), the area of land under cultivations has increased, and livestock numbers have risen considerably. Both the latter processes have been associated with wetland desiccation, water pollution, more severe surface runoff, loss of soil fertility and an increasing number of conflicts over resource use, especially between farmers and livestock keepers (Kangalawe and Liwenga 2005, p. 970). In addition, wildlife numbers have declined, and the clashes between conservation interventions and the activities of farmers in the villages have become steadily more severe (Nindi 2014).

Since the majority of people in the Kilombero Valley live and work on protected land, human encounters with wildlife occur regularly when various species enter human settlements and agricultural land (Kangalawe and Liwenga 2005). As Bonnington et al. (2009, p. 280) have observed, this is also due to the fact that the entire valley functions as a migration corridor for large game moving from the mountains down to the river. Nevertheless, over the last twenty years seasonal animal migration through the valley has almost come to a standstill. Generally, reports and publications refer to the increases in human population, livestock, deforestation and rice cultivation as its root causes (Jones et al. 2012), whereas other aspects, such as illegal hunting, the wildlife trade and logging, which may also go beyond the influence of village populations, are rather neglected (Bonnington et al. 2007a, b).

\section{Situating Corridors in Larger Conservation Efforts}

According to local residents, while some animals still try to pass through the corridors, they often turn back after setting foot on farmland. Thus, movements only take place close to the protected areas, which is where crop damage and conflictual situations occur most often. Elephants, for instance, regularly damage crops on village land, and chasing them away can be deadly for both humans and animals (Masunzu 1998). Nevertheless, the attempts of wildlife to cross give reason to hope that the connectivity between different habitats and different protected areas can actually be restored. In particular, four former wildlife corridors have been identified by NGOs and researchers and have now become the subject of restoration efforts. Three of them lead from the Udzungwa Mountains National Park and the Kilombero Nature Reserve down to the river and up to Nyerere National Park and the Selous Game Reserve (Mwanihana-Magombera, Ruipa and Nyanganje). The fourth corridor at Mngeta connects Udzungwa Scarp and the Kilombero Nature Reserve (Rovero and Jones 2012).

Ideally, the corridors should be created by the migrating animals themselves according to their needs. If they were, they often transcended and crossed existing conservation efforts, which have long focused on a more rational spatial planning of 
the local economy (see, e.g. Garland 2008, 59 ff.; Lekan 2011). Situated outside the official conservation areas, the corridors have therefore long been neglected. Only recently, in line with a more comprehensive shift in conservation science away from the protection of single species and a focus on fenced-off areas towards landscapeecological concepts, a new emphasis is being placed on corridors and their decisive role as connecting structures for the migration of species over distances in order to satisfy their vital needs (Flitner 2005; Newmark 2008; Goldman 2009; Howell et al. 2012). Recent research, as well as different practical interventions in the corridors of the Kilombero Valley, also testifies to this new interest in corridors as target areas for 'conservation-as-development' (Adams 2020).

However, although they are turning into a standardized tool of conservation practice, corridors still tend to rely on the separation of wildlife from spaces used by humans. Yet, as pointed out earlier, such exclusive regimes of conservation have not only been criticized for how they are conceptualized, they do not even seem feasible (Goldman 2009). Therefore, the protection and restoration of corridors faces the particular challenge of reconciling different land-use regimes and patterns of land ownership in order to enable seasonal animal migrations. As Noe (2010), for example, shows for southern Tanzania, hybrid spatial patterns are gaining momentum in relation to the lack of any protection status for the corridors. By drawing on empirical work on the corridor connecting the Selous Game Reserve with the Transfrontier Conservation Area (TFCA) between Tanzania and Mozambique, she illustrates how integrating community, reserved and private categories of land into the corridor project contrasts with the earlier containment policies of national states and parks. In the end, the conservation of corridors formally becomes effective in mosaic landscapes of private, state and public land (Adams 2020), in which land use is supposed to go hand in hand with its protection (Ramutsindela and Noe 2012). To reach this goal, and in contrast to simply fencing them off, forests are re-created, trees are planted, and corridors are actively restored with the participation of local residents.

\section{The Corridors' Local Embedding}

The activities of the AWF, which follow the aspirational politics of 'conservationas-development' described earlier, are also challenged by the diverse forms of land use and different land rights in the Kilombero Valley. So far, participatory conservation efforts in this part of Tanzania have focused on special regulations for protected areas, for example, when local support in conservation revolved around keeping the surrounding inhabitants out of the forests. This task became more demanding when the Wahehe, who considered the forested mountains, with their large caves, to be holy places and thus inviolable, had to leave the higher altitudes and move into the valley when the Kilombero Nature Reserve was founded in 2007. Although part of the Ruipa Corridor was given a protected status in the process, the establishment of this new nature reserve has nevertheless further concentrated the population in the valley lowlands. While the Wahehe are still known to support forest protection, conservation interests are becoming more and more difficult to impart to the more recent newcomers. The latter are often characterized as pastoralists or agro-pastoralists and 
are segregated on the basis of their land use, which often extends into protected areas and village forests (interview with Division Forest Officer 2018, Ihenga).

Besides mounting exhausting and dangerous patrols to keep the forests untouched and intact, wildlife officers inform the surrounding villagers about the penalties for poaching and stress the importance of species protection and biodiversity. In turn, the villagers are expected to report suspicious behaviour and to call the officers as soon as they observe any illegal activities on protected land. However, this hardly happens, and cutting down trees for timber or charcoal, growing rice or maize and even hunting game inside the reserves continue (interview with Wildlife Officer 2018, KNR). To secure animals' vital access to water through the Ruipa corridor, in the past armed officers have accompanied the animal's seasonal migration in order to protect animals and humans from each other. In contrast, in the ongoing project, the restoration of the wildlife corridors is to be carried out by the local communities themselves by leaving spaces as open as possible or reducing human use in them to allow the passage of wildlife. The motivation for their active engagement is supposed to arise in the light of the benefits suggested by 'restoration-as-development'. Yet, as Finnemore and Jurkovich (2020) have pointed out, the effectiveness of an aspiration strongly depends on the value attached to it by a collective of aspirants-in this case, the surrounding villagers in the corridors (see also Huijmans et al. 2021). As this brief introduction to the Kilombero Valley and the contested spaces of animal migration has already indicated, the successful realization of restoring wildlife corridors thus clearly depends on the ways in which this global policy aspiration is brought into interaction and aligned with potentially divergent local concerns and desires.

\section{Coming Down to Earth: Contesting Restoration as a Future Path to Development and Conservation in Kilombero Valley}

Even though global environmental governance must still be organized very hierarchically to be able to dictate its aspirations 'downwards', so far only a few scholars have tried to understand better how those who actually accept, execute, appropriate, protest against and transform these aspirations can still be treated as mere spectators or uninvolved recipients (Kurniawan and Kundurpi 2019). It is in this spirit that we have examined the ways in which ROAM is being used by the AWF in the Kilombero Valley to restore wildlife corridors. In order to gain thorough insights, we followed an ethnographic approach, which included three months of participant observation in early 2018, when one of the authors was able to join the AWF's activities in this part of Tanzania. Another three months followed in 2019 in which we were able to see and discuss how things had developed in the meantime, and there was also a shorter follow-up visit in early 2020. Building on and complementing the institutional ethnography with the AWF, we conducted eighteen semi-structured interviews. We talked to villagers, NGO workers, local leaders, foresters and wildlife officers who were involved in the restoration of wildlife corridors. The interview transcripts have been translated and subjected to qualitative content analysis (McDowell 2010). 
Through these different approaches, it soon became clear that the idea of the restoration of wildlife corridors in the Kilombero Valley has led to complex negotiations and different effects in different local settings. While the AWF, the wildlife officers and foresters aspire to recreate spaces and habitats for the migration of large game, the life of the villagers has generally become easier with less wildlife roaming through their neighbourhoods, since these spaces now provide an income for farmers and pastoralists through rice cultivation and livestock breeding. In consequence, the different actors are seen to commit themselves in very different ways to support the realization of the project's aspirations. Following the idea that local aspirations take or change shape through exposure to different ideas and information that convey images of success, as these may push people to adapt their views of a desired future in certain directions, it is particularly the different participatory activities employed in the project that form the focus of the analysis. In the following, this article will therefore turn to specific situations and encounters during the participatory phases of the project which aim at empowerment, capacity-building and increasing the landscape's productivity, discussing them critically in the light of the local dynamics. This will permit a better understanding of how the aspiration to restore forest landscapes, as expressed by the Bonn Challenge and ROAM, is appropriated, challenged or played along with by the diverse local actors, finally rendering the restoration of wildlife corridors something of an illusion.

\section{Restoration as Empowerment: Appropriating Aspirations to Serve the Villagers' Interest}

Empowerment is deeply embedded in the design of participatory projects. With different focuses on gender, age, disability or political participation, empowerment has become a goal and mechanism in the majority of development projects, including community development in rural areas of the Global South (Craig 2002; Cornwall and Brock 2005). Cornwall and Brock (2005) have criticized the inflationary use of this buzzword in policies, producing a depoliticizing, optimistic, technical and solution-based jargon, which sometimes mainly seems to benefit the legitimacy of the development elite itself, rather than actually empowering the other project participants. Despite some changes over time in the measures and exercises that are supposed to fulfil the idea of empowerment (Toomey 2009), the basic component still consists in the active involvement of local initiatives, ideas and leadership in all phases of a project (Craig 2002). Achieving this is also presented as a major goal when the AWF is presenting the project in the villages next to the wildlife corridors that are to be restored.

One of the corridors is supposed to cross the Namwai forest, a joined village forest reserve linking the villages of Ihenga, Idandu and Kisegese. Despite clear regulations, according to the community-based forest management governing this forest reserve, with increasing use of forest land and resources, it has become hard to distinguish the former forest land from the surrounding rice fields. Moreover, there are a few huts scattered around and some herds of cattle grazing on the site. This situation will now be reversed in the restoration project, the first step in 
this direction being for the AWF to present itself and the project's ideas at local village meetings. These meetings are conducted under the auspices of the village government and should ideally include all the actors involved. However, they are attended primarily by the Wenyeji, the local tribes, which claim to be indigenous and mostly engage in agriculture. According to them, many negative developments in the landscape, including the deterioration of the wildlife corridors, are associated with the newcomers - mainly pastoralists and agro-pastoralists-who have moved into the Kilombero Valley over the last twenty years (interview with elder 2018, Mofu). As one farmer claimed at the village meeting:

My hope is that Kilombero will be like it used to be: I was getting 25 bags of rice, but right now it is only six! Most of the ponds are gone because of the immigrants and their cattle. The soil is compacted, the water infiltration is less, so production is low. (interview with farmer 2018, Ihenga)

The majority of those present at the meeting all agreed, and in our conversations, it became clear that deforestation, changing rain patterns, the drying up of rivers, poorer harvests and the emergence of diseases and pests are widely associated with these newcomers. Some of the villagers also openly envy the pastoralists for having been able to acquire large areas of land of the Namwai Forest for their cattle and for the large houses, they have built there (interview with elder 2018, Ihenga). The state's failed attempts to expel the pastoralists from the Kilombero Valley in 2012 further strengthened their image as powerful enemies (Bergius et al. 2020). As one elder stated:

The immigrants are more powerful than the government. Those people are powerful because last year in August the district commissioner came and said, he gave an order, that all people should be evicted, should move out of that area [Namwai Forest]. But those people are still there and increasing. (interview with elder 2018, Mofu)

However, a lot of this land was sold to them illegally by local leaders. Shifting the boundaries of the reserve as they saw fit, they have profited from such sales while laying the foundations for the migrants to clear the land, grow rice and let their cattle graze on it. Nonetheless, any discussion of this involvement by the villagers is carefully avoided in the village meeting. As the (agro)pastoralists have not yet been directly addressed and included, these meetings provide a forum for the farmers to voice their concerns and present the pastoralists as the sole culprits. The AWF too refrains from assigning blame and responsibility for the degraded forest to the village authorities. In order to fulfil the requirements of their participatory approach and to obtain a permit for restoration from the village leaders, the AWF depends on the cooperation of the local population. Indeed, presenting the project offers them a window of opportunity: from the villagers' perspective, the restoration of wildlife corridors may finally provide another reason to displace the (agro)pastoralists.

This shows how external aspirations may be co-opted and manipulated by certain actors as profiteers (Finnemore and Jurkovich 2020). The aspiration to 
restore the wildlife corridor in an inclusive way is appropriated by the Wenyeji to serve their own interests. As a result, in the light of the conflict between farmers and herders, restoration efforts fail to strengthen local actors equally and become an act of selective empowerment for the local farmers drawing on the support of the AWF as an external actor.

In the end, however, even though the village leaders would certainly appreciate the eviction of the pastoralists as part of the restoration effort, they still hesitated to approve the project. They generally fear outside interference, which might fuel the conflicts between the farmers, the pastoralists and the village leadership further. They also want to avoid attracting attention to their illegal land sales, which would certainly be revealed in the course of the pastoralists' expected protests. Thus, despite the AWF's efforts to encourage the local communities around the Namwai forest to share their aspirations to restore wildlife corridors by offering them the lead in decision-making, the implementation of ROAM is still stagnating in this part of the wildlife corridor.

\section{Restoration as Capacity-Building: Playing Along Despite Disagreement}

Apart from obtaining permission from the village leadership, ROAM requires the collaboration of all the actors in a landscape, including the landowners and various professionals. To negotiate the different forms of land use and their future is one of the project's greatest challenges and should be guaranteed by enhancing the knowledge and capacities of the local community to support the process of restoration. Like the idea of empowerment, capacity-building too is a tangible response to the criticism of technical assistance in development cooperation. The unidirectional transfer of allegedly superior and more genuine knowledge and technology from the Global North to the Global South was discredited in order to exacerbate global hierarchies and dependencies. Since the 1990s, particularly through initiatives by the World Bank and the United Nations Development Programme (UNDP), the capacity-building approach has mushroomed in development and encouraged recognition of the social context of knowledge (Sen 1992; Cherlet 2014, p. 785; Nussbaum 2016).

With regard to the restoration of wildlife corridors in the Kilombero Valley, once the initial concessions in a village have been acquired, capacity-building is supposed to occur through the restoration activities. To start these, the AWF organized a treeplanting day in the village of Njage, where, in contrast to the villages around the Namwai forest, the residents and authorities soon agreed to the project. To attract a good number of participants through a series of workshops, briefings and sensitization campaigns, tree-planting had been introduced earlier as a practice that would successfully link the need for reforestation with capacity-building. Moreover, treeplanting seems to offer a way of translating the aspirations of restored wildlife corridors into a concrete commitment to act:

So, my hope is that all the forest will come back. There is some evidence of that: in the previous years, no one asked for trees or they did not want to buy or plant. But right now it is like people are awake and they come, they want tree 
seedlings: we want to buy and do this! (interview with Division Forest Officer 2018, Ihenga)

But the event itself clearly shows that participation is about more than just treeplanting. Such participatory events, which are organized regularly by the different NGOs that are active in the area, advance, complement and sometimes even replace formal negotiations, knowledge-sharing and the more official capacity-building workshops. As a social and political happening, tree-planting by volunteers together with government officials, village leaders, NGO staff, farmers, church leaders and women's groups is used by the different actors to communicate their respective interests, while at the same time already moving forward with the restoration activities. The trees themselves almost disappear in the shadow of entertainment, food, soda and posing for newspaper pictures reporting the success of the event. Nevertheless, attracted by the gathering and a free meal, at least at first sight it seems as if the farmers are playing along with the aspiration to restore the forests by participating in the planting of trees.

The trees that are planted on such occasions are usually taken from one of the tree nurseries in the Kilombero Valley. Hidden in small patches among villages, reserves, missionary centres, schools and military bases, this is where villagers and committed institutions are trained to care for the raising of young plants. As part of the project, the AWF has distributed 170,000 tree seedlings purchased from the Tanzania Tree Seed Agency. The selection and proper handling of these seedlings will be crucial to the success of the project. Whereas private nurseries often specialize in cash crops, such as cocoa, timber or ornamental plants, public tree nurseries are currently in a global downturn, while in Tanzania, government support has been reduced considerably since the 1980s. Nonetheless, such nurseries remain crucial sites for capacity-building through training events, research and the multiplication of native and less profitable varieties. A closer look at these nurseries reveals that they do not just form a space for the straightforward dissemination of knowledge from global platforms and internationally trained officers to local communities. Rather, it is in these tree nurseries that knowledge and ideas about the proper restoration of the corridors are negotiated and contested.

According to the project, and inspired by its role model in Rwanda, native as well as exotic species are maintained in the tree nurseries. The villagers, however, express a clear preference for native species, namely Faidherbia albida, Markhamia lutea, Khaya anthotheca, Afzelia quanzensis and Albizia schimperiana, as it is only with native species, the villagers say, that wildlife, including the migrating animals, will return. It is especially those elders and Wenyeji who once lived inside the nature reserves who emphasize the value of such tree species in the forests for the landscape's particular hydrology and sensitive connections with other species.

[In the past] you could pass through the forest, and it felt like it was raining. But it was not raining. It was just the water retention by those trees. The water resources were always filled because of those trees, but it is difficult to return to that situation, as you cannot find many of those trees anymore. With the loss of those trees, you also lose the birds living in them, since they are not used to coconut trees, for instance. (interview with elder 2018, Mngeta) 
Ecologically, the planting of non-native species is a controversial issue because of the unexpected changes they may cause to ecosystems, including invasive infestations and the eradication of native species (Chazdon and Uriarte 2016).

If you plant a teak tree, first of all, this is not a water-friendly tree, because it absorbs like sixty litres per day, one fully grown tree. Those are invasive species. We avoid them. If you plant it, even the leaves that fall down will change the vegetation. If we plant a new tree species, this will be like another ecological system. You never know what will happen. But we would like to see the same animals coming back for this vegetation. (interview with member of the community-based resource management 2018, Mofu)

Yet, despite these concerns, exotic species are being planted as part of this project, as they are said to be more resistant to stress, having a wider ecological amplitude and competitiveness. Moreover, it is especially the faster growth of exotic species such as Acacia mangium, Gmelina arborea, Terminalia ivorensis, Leucaena leucocephala and Acrocarpus fraxinifolius that complies with the project's logic. In contrast, the functions of trees in the ecosystem itself, such as providing shade for other plants or food for migrating species, are hardly considered in making this selection (Butterfield et al. 2016). Consequently, the training workshops in the tree nurseries or on the tree-planting days are characterized by negotiations between international experts, local implementers and affected residents. Here, different forms of knowledge meet and are either approved or rejected in the (re)production of power structures. This became particularly evident when two local caretakers at the municipality's tree nursery approached an AWF officer during one of our visits to the villages along the corridor. The caretakers proudly reported that they had been able to buy some cheap tree seedlings from Tanga, on the coast of northern Tanzania. As the species involved are supposed to be good for riverbanks and fish populations, they wanted to plant them along the rivers of the Kilombero Valley to be able to do more fishing. The AWF officer, in surprise, replied:

"Have you ever thought about ecology? Maybe the species in Tanga are good for the rivers there. It's a different ecological system here! We are not just talking about trees! An ecological system is much bigger and has many more components. Do you know what it does to insect populations, for example, or to other plants and animals? You cannot plant these trees!" (AWF officer 2018, Mngeta)

In this case, the difference between apparent expert knowledge and local ways of dealing with the environment is not all that divergent, for the AWF officer seems to agree with the local community that planting exotic species may indeed have unintended consequences. But while the AWF nevertheless assumes the right to decide about the specific species to be planted, this right is not granted to the local population. In this way, the project's activities illustrate how the globally unequal transfer of knowledge and technology is shifted to the local level through the capacity-building paradigm. As in most development projects, it is 
the local academic elite working for (international) NGOs, trained in the western style at universities and using global policy tools, in this case ROAM, that dominates the locally embedded knowledge that should, at least on paper, form the basis for capacity-building by communities. So, after all, when the tree-planting day comes to an end, it is the external experts who decide which species may be planted and which are to be rejected, thus making the experts dominant in shaping the future of the landscape.

In this regard, the restoration activities are not very different from conventional participatory training workshops. Even though the villagers do not share a consensus themselves on the extent to which they agree with the experts' decisions on the choice of exotic and native species, they accept the choice, at least on the surface. Knowing that to realize their aspirations to restore native species would be too timeconsuming, costly and therefore not feasible in the context of this project, local communities play along with an approach to restoration they are less in favour of. Ultimately, the hope of turning the promise of 'restoration-as-development' into a reality and generating profits at the local level remains.

\section{Restoration as Productivity: From Aspiration to Illusion}

When discussing the Kilombero Valley as a functional and productive forest landscape that is aspired and to be realized through ROAM, different aspects of the landscape to be restored matter. Overall such aspirational politics, being formulated in terms of unattainable goals, set few standards of feasibility, but rather emphasize the efforts made in the name of the goals. In this respect, the future success of ROAM in the landscape is to be measured and evaluated first of all on the basis of how much planned forest cover has actually been grown. This is especially a matter of the number of hectares that have been planted, even though this is not very indicative of the future ecosystem and its benefits for the inhabitants of the valley. Since expected growth rates appear to determine the decision to go for fast-growing exotic species, these will shape the physical and material design of the future landscape. Moreover, the choice of trees also affects their potential use by both humans and animals. In this respect, the argument for exotic species always involves a cost-benefit calculation, which includes the desire to enhance adaptive capacities and build a resilient ecosystem with a potentially positive output for native species as well (Butterfield et al. 2016). In this regard, the preventive idea of not letting past environmental problems reoccur and cause extensive degradation plays a crucial role. Furthermore, species for human use, such as firewood, timber and livestock plants, are supposed to become part of the corridors, with agroforestry offering additional opportunities for local livelihoods and thus allowing the project to realize the goal of 'conservation-as-development'.

The two major species that are expected to create a more productive landscape in the Kilombero Valley are cocoa and teak. However, the fact that agroforestry as envisaged is supposed to create more income than conventional practices usually falls on deaf ears among the villagers. Even those villagers who would like to reclaim the forest for their agricultural practices are concerned about who will 
decide how the landscape will be reshaped, the long time it will take for the new landscaping actually to become productive, and to what extent this will actually contribute to the revitalization of wildlife migration.

The Kilombero Valley Teak Company outgrower programme, in which individual villagers plant teak on their land and sell the harvest to the company, indicates this problem. The plantations are staggered by age and usually exist for up to fifteen years until the trees are cut and sold. As some farmers state, due to economic pressures, it appears to them unlikely that such teak trees will have a future in the corridors, which lack the clear regulations of the Kilombero Valley Teak Company.

Because of the increasing population, there is no way the size of the forest can be expanded; it will rather be reduced. And those trees planted for business, they will be cut for timber. So it will soon look again like it does now. (interview with farmer 2018, Mngeta)

Moreover, observations from recent years show that it is only in the most recent plantations that animals such as monkeys, buffaloes, elephants and their predators can be found, as these herbivores prefer to feed on grass and bush species. They are still abundant in the first years of the teak plantation, but foliage layers change as the trees age, the crowns then forming a dense canopy, and fallen leaves cover the grasses and the herbaceous layer. In the long run, even though teak may contribute to a forest-like appearance of the land and provide additional income, it does not provide a habitat for the migrating species and thus may rather act against the revitalization of the wildlife corridors (Bonnington et al. 2007a, b).

Regarding new cocoa trees in restored corridors, many farmers fear a rise in clashes between humans and animals when elephants enter the plantations to feed on cocoa. Finally, the farmers also worry about increasing conflicts between themselves and the pastoralists when the latter are actually driven out of the corridors to make way for the new agroforest systems and will eventually have to take their cattle even closer to the villages and farms.

Thus, while it appears difficult for the AWF to cultivate long-term aspirations to restore wildlife corridors to the local communities, the organization prefers to focus on the immediate future. Its main concern is that its monitoring and evaluation surveys should demonstrate clear initial achievements, as reflected in the numbers of village meetings, training sessions conducted in the target regions, expert workshops, tree seedlings acquired and raised and the size of the planted areas. These first results, even if incomplete, are a way for its experts to get the restoration project extended for a couple of years and, as a result, their own work contracts as well. Thus, even though restoration ecology scholars agree that restoring a landscape can take a lifetime, the story of 'conservation-as-development' as a success has to begin now, even if it appears to be an illusion. Otherwise, the AWF officers would have to leave the area at the end of the first funding phase and start looking for new conservation areas to restore somewhere else in Tanzania. Following the logic of development rather than of restoration ecology, in creating a future for the project their main goal translates into the production of numbers that say very little about actual restoration and hide how little the global policy aspirations that are driving the project are shared locally. 


\section{Conclusion}

Wildlife corridors in the Kilombero Valley, Tanzania, are supposed to link protected areas to allow for species migration. However, due to the expansion of agricultural and grazing land over the past twenty years and their resulting degradation, active engagement by humans is needed to support any return by migrating wildlife. In line with global efforts to promote the restoration of degraded and deforested land, the African Wildlife Foundation (AWF) has been given the task of implementing the Restoration Opportunity Assessment Methodology (ROAM) recently developed by the IUCN and the World Resources Institute to foster the restoration of wildlife corridors in the area. Designed as a collaborative endeavour involving the different actors living in, using and governing the selected land, it is in this process that the aspirations associated with global restoration policies are confronted with a specific local context.

In following the idea of 'conservation-as-development', the project attempts to provide incentives for the local communities to gain their approval and commit themselves to the project's aspiration to restore forest landscapes in the corridors. However, since wildlife corridors are not usually supposed to be cultivated, nor expected to participate in tourism activities and related forms of income generation, they do not seem to offer much potential for the economic benefits that are generally proclaimed in 'conservation-as-development' initiatives. The project's activities therefore focus on the empowerment of local communities, capacitybuilding and the enhanced productivity of the landscape through new agroforestry systems. However, empirical research has shown that these objectives and related processes are difficult to implement, as they come down to earth in a setting characterized by the potential for conflict over different land-use regimes.

As our ethnographic insights from village meetings, tree-planting days, tree nurseries and our visits to the corridors reveal, the goals of empowerment, capacity-building and new forms of productivity therefore largely fail to be reached, as the different actors do not simply adopt the project's underlying aspirations but appropriate them to serve their own interests, playing along with them mainly to benefit from side events, or even openly rejecting them as they are not aligned with their own experiences and thus rather seem to be an illusion. Thus, while the participatory measures are meant both to start the restoration process and, at the same time, enhance local capacities to share global policy aspirations, it becomes clear that local aspirations do not simply develop as anticipated through their exposure to external influences. Even though local aspirations may change in the course of the interactions, as Baillergeau and Duyvendak (2019, p. 6) have pointed out, "there is no guarantee that the change is in the desired direction [as] interactions can encourage a person's capacity to aspire to blossom, but also to wither away". Even though tree-planting workshops may help to transform aspirations into capabilities, these are not sufficient to overcome the scepticism and doubts regarding their feasibility and functioning. In effect, support for the corridors among the local population seems rather to have declined over the course of the project. After all, apart from a few nostalgic voices about past animal 
migrations, the corridors are mainly seen as the settings of conflicts either with wild animals or between farmers and (agro)pastoralists.

As this article shows, these conflicts play a major role in the ways in which the project's ideas are contextualized locally, despite hardly being incorporated in the formulation of global policy goals. Hence, while the villagers in the Kilombero Valley, unimpressed by the activities of the AWF, tend to stick to their "habituated aspirations", which relate more closely to the "latently felt estimations of probable futures" (Zipin et al. 2015, p. 234), the restored wildlife corridors remain what they are-an illusion of aspirational politics.

Funding Open Access funding enabled and organized by Projekt DEAL.

Open Access This article is licensed under a Creative Commons Attribution 4.0 International License, which permits use, sharing, adaptation, distribution and reproduction in any medium or format, as long as you give appropriate credit to the original author(s) and the source, provide a link to the Creative Commons licence, and indicate if changes were made. The images or other third party material in this article are included in the article's Creative Commons licence, unless indicated otherwise in a credit line to the material. If material is not included in the article's Creative Commons licence and your intended use is not permitted by statutory regulation or exceeds the permitted use, you will need to obtain permission directly from the copyright holder. To view a copy of this licence, visit http://creativecommons.org/licen ses/by/4.0/.

\section{References}

Adams, W.M. 2012. Conservation in the Anthropocene: Biodiversity, poverty and sustainability. In Biodiversity conservation and poverty alleviation: Exploring the evidence for a link, ed. W. Cooper, D. Roe, J. Elliott, C. Sandbrook, and M. Walpole, 304-315. Oxford: Wiley-Blackwell.

Adams, W.M. 2020. Geographies of conservation III: Nature's spaces. Progress in Human Geography 44 (4): 789-801.

Baldus, R.D., L. Siege, and S. Numßen. 2007. Eine afrikanische Legende. Großwildjäger und Naturalist Frederick C. Selous. Visier 5: 54-62.

Bamford, A., D. Ferrol-Schulte, and E.M.S. Belle. 2011. A wildlife corridor under severe threat in the Kilombero Valley, Tanzania. The Earth Time. 5 October: 1. http://www.earthtimes.org/conservati on/wildlife-corridor-under-severe-threat-kilombero-valley-tanzania/1471/. Accessed 17 Mar 2020.

Baillergeau, E. and J.W. Duyvendak. 2019. Dreamless futures: a micro-sociological framework for studying how aspirations develop and wither. Critical Studies in Education 1-16.

Benjaminsen, T.A., M.J. Goldman, M.Y. Minwary, and F.P. Maganga. 2013. Wildlife management in Tanzania: State control, rent seeking and community resistance. Development and Change 44: 1087-1109.

Bergius, M., T.A. Benjaminsen, F.P. Maganga, and H. Buhaug. 2020. Green economy, degradation narratives, and land-use conflicts in Tanzania. World Development 129 (104850): 1-13.

Bonnington, C., D. Weaver, and E. Fanning. 2007a. The use of teak (Tectona grandis) plantations by large mammals in the Kilombero Valley, Southern Tanzania. African Journal of Ecology 47: 138-145.

Bonnington, C., D. Weaver, and E. Fanning. 2007b. Livestock and large wild mammals in the Kilombero Valley, in southern Tanzania. African Journal of Ecology 45: 658-663.

Brockington, D. 2002. Fortress conservation: The preservation of the Mkomazi Game Reserve, Tanzania. Oxford: James Currey.

Büscher, B., and M. Arsel. 2012. Introduction: Neoliberal conservation, uneven geographical development and the dynamics of contemporary capitalism. Tijdschrift voor economische en sociale geografie 103: 129-135.

Butterfield, B.J., S.M. Copeland, S.M. Munson, C.M. Roybal, and T.E. Wood. 2016. Prestoration: Using species in restoration that will persist now and into the future. Restoration Ecology 25 (2): 155-163. 
Chazdon, R.L., and M. Uriarte. 2016. Natural regeneration in the context of large-scale forest and landscape restoration in the tropics. Biotropica 48 (6): 709-715.

Chen, Jun, Jin Chen, A. Liao, X. Cao, L. Chen, X. Chen, C. He, G. Han, S. Peng, M. Lu, W. Zhang, X. Tong, and J. Mills. 2015. Global land cover mapping at 30m resolution: A POK-based operational approach. ISPRS Journal of Photogrammetry and Remote Sensing 103: 7-27.

Cherlet, J. 2014. Epistemic and technological in determinism in development aid. Science, Technology, and Human Values 39 (6): 773-794.

Cornwall, A., and K. Brock. 2005. What do buzzwords do for development policy? A critical look at 'participation', 'empowerment' and 'poverty reduction. Third World Quarterly 26 (7): 1043-1060.

Craig, G. 2002. Towards the measurement of empowerment: The evaluation of community development. Journal of the Community Development Society 33 (1): 124-146.

Dinesen, L. 2016. Kilombero Valley Floodplain (Tanzania). In: The Wetland Book, eds. C. M. Finlayson Finlayson, G. Milton, R. Prentice, and N. Davidson, 1-8. Dordrecht: Springer.

Ellis, E.C. 2015. Too big for nature. In After preservation: Saving American nature in the age of humans, ed. B.A. Minteer and S.J. Pyne, 24-31. Chicago: University of Chicago Press.

Ellis, E.C., and N. Ramankutty. 2008. Putting people in the map: Anthropogenic biomes of the world. Frontiers in Ecology and the Environment 6 (8): 439-447.

Finnemore, M. and M. Jurkovich. 2020. The politics of aspiration. International Studies Quarterly 0: $1-11$.

Flitner, M. 2005. Inszenierte Natur, postkoloniale Erinnerung: „Serengeti darf nicht sterben“. In Themenorte, ed. M. Flitner and J. Lossau, 107-124. LIT: Münster.

Folke, C. 2006. The economic perspective: Conservation against development versus conservation for development. Conservation Biology 20: 686-688.

Garland, E. 2008. The elephant in the room: Confronting the colonial character of wildlife conservation in Africa. African Studies Review 51 (3): 51-74.

Goldman, M. 2003. Partitioned nature, privileged knowledge: Community-based conservation in Tanzania. Development and Change 34: 833-862.

Goldman, M. 2009. Constructing connectivity: Conservation corridors and conservation politics in East African rangelands. Annals of the Association of American Geographers 99 (2): 335-359.

Goldman, R.L., G.C. Daily, and P. Kareiva. 2010. Trade-offs in making ecosystem services and human well-being conservation priorities. In Trade-offs in conservation: deciding what to save, ed. $\mathrm{N}$. Leader-Williams, W.M. Adams, and R.J. Smith, 56-73. Oxford: Wiley-Blackwell.

Higgs, E., D.A. Falk, A. Guerrini, M. Hall, J. Harris, R.J. Hobbs, S.T. Jackson, J.M. Rhemtulla, and W. Throop. 2014. The changing role of history in restoration ecology. Frontiers in Ecology and the Environment 12 (9): 499-506.

Howell, E.A., J.A. Harrington, and S.B. Glass. 2012. Introduction to restoration ecology. Washington: Island Press.

Hughes, R., and F. Flintan. 2001. Integrating conservation and development experience: A review and bibliography of the ICDP literature. London: International Institute for Environment and Development.

Huijsmans, R., N. Ansell, and Froerer., P. . 2021. Editorial Introduction: Development, Young People, and the Social Production of Aspirations in Young Lives. European Journal of Development Research 33 (1): 1-15.

International Union for Conservation of Nature (IUCN). 2020. Restore our Future. Bonn Challenge. Impact and Potential of Forest Landscape Restoration. Bonn Challenge. Arizona. http://www.bonnc hallenge.org. Accessed 17 Mar 2020.

International Union for Conservation of Nature (IUCN). 2018. Restoration Opportunities Assessment Methodology (ROAM). Jacksonville. https://www.iucn.org/theme/forests/our-work/forest-lands cape-restoration/restoration-opportunities-assessment-methodology-roam. Accessed 17 Mar 2020.

International Union for Conservation of Nature (IUCN). 2017. The Bonn challenge. IUCN. Washington. http://www.bonnchallenge.org. Accessed 17 Mar 2020.

International Union for Conservation of Nature (IUCN) and World Research Institute (WRI). 2014. A guide to the Restoration Opportunities Assessment Methodology (ROAM): Assessing forest landscape restoration opportunities at the national or sub-national level. Working Paper (Road-test edition). (IUCN) Gland.

Jarvis, A., H.I. Reuter, A. Nelson, and E. Guevara. 2008. Hole-filled seamless SRTM data V4. International Centre for Tropical Agriculture (CIAT). http://srtm.csi.cgiar.org. Accessed 17 Mar 2020. 
Jones, T., A.J. Bamford, D. Ferrol-Schulte, P. Hieronimo, N. McWilliam, and F. Rovero. 2012. Vanishing wildlife corridors and options for restoration: A case study from Tanzania. Tropical Conservation Science 5 (4): 463-474.

Kangalawe, R.Y.M., and E.T. Liwenga. 2005. Livelihoods in the wetlands of Kilombero Valley in Tanzania: Opportunities and challenges to integrated water resource management. Physics and Chemistry of the Earth 30: 968-975.

Kurniawan, J.H., and A. Kundurpi. 2019. Integrating human geography into futures studies: Reconstructing and reimagining the future of space. Geography Compass 13 (6): e12443.

Lekan, T. 2011. Serengeti shall not die: Bernhard Grzimek, wildlife film, and the making of a tourist landscape in East Africa. German History 29: 224-264.

Matzek, V., E.S. Gornish, and K.B. Hulvey. 2017. Emerging approaches to successful ecological restoration: Five imperatives to guide innovation. Restoration Ecology 25 (2): 110-113.

Mazunsu, C. 1998. Assessment of crop damage and application of non lethal deterrents for crop protection East of the Selous Game Reserve. In Tanzania Wildlife Discussion Paper. 24, eds. L. Siege and R. D. Baldus, 1-20 Dar es Salaam: Wildlife Division Tanzania and Deutsche Gesellschaft für Technische Zusammenarbeit.

McDowell, L. 2010. Interviewing: Fear and liking in the field. In The SAGE handbook of qualitative geography, ed. D. Delyser, S. Herbert, S. Aitken, M. Crang, and L. McDowell, 156-171. London: SAGE Publishing.

Nelson, F., and A. Agrawal. 2008. Patronage or participation? Community-based natural resource management reform in Sub-Saharan Africa. Development and Change 39: 557-585.

Neumann, R.P. 1995. Local challenges to global agendas: Conservation, economic liberalization and the pastoralists' rights movement in Tanzania. Antipode 274: 363-382.

Newmark, W.D. 2008. Isolation of African protected areas. Frontiers in Ecology and the Environment 6 (6): 321-328.

Newmark, W., and J.L. Hough. 2000. Conserving wildlife in Africa: Integrated conservation and development projects and beyond. BioScience 50: 585-592.

Nindi, S.J., H. Maliti, S. Bakari, H. Kija, and M. Machoke. 2014. Conflicts over land and water resources in the Kilombero Valley Floodplain, Tanzania. African Study Monographs 50: 173-190.

Noe, C. 2010. Spatiality and 'borderlessness' in transfrontier conservation areas. South African Geographical Journal 92 (2): 144-159.

Nussbaum, M.C. 2016. Introduction: Aspiration and the capabilities list. Journal of Human Development and Capabilities 17 (3): 301-308.

Ramutsindela, M., and C. Noe. 2012. Scalar thickening: Wildlife management areas and conservation scales in southeast Tanzania. Singapore Journal of Tropical Geography 33 (1): 137-151.

Rovero, F., and T. Jones. 2012. Wildlife corridors in the Udzungwa mountains of Tanzania. Ecological Restoration 30 (4): 282-195.

Sen, A. 1992. Inequality reexamined. New York: Russell Sage Foundation.

Smith, D.E. 2005. Institutional ethnography: A sociology for people. Lanham, MA: AltaMira Press.

Toomey, A. 2009. Empowerment and disempowerment in community development practice: Eight roles practitioners play. Community Development Journal 46 (2): 181-195.

United Nations Environment Programme (UNEP) - World Conservation Monitoring Centre (WCMC) \& International Union for Conservation of Nature (IUCN). 2021. Protected planet: The World Database on Protected Areas (WDPA) and World Database on Other Effective Area-based Conservation Measures (WD-OECM). Cambridge. www.protectedplanet.net. Accessed 17 Mar 2020.

United Republic of Tanzania (URT). 2013. 2012 population and housing census. Dar es Salaam: Government Printer.

Vaccaro, I., O. Beltran, and P.-A. Paquet. 2013. Political ecology of conservation: Some theoretical genealogies. Journal of Political Ecology 20: 255-272.

West, P. 2006. Conservation is our government now. Durham, NC: Duke University Press.

World Resources Institute (WRI). 2018. AFR100. Washington. http://afr100.org/content/tanzania. Accessed 17 Mar 2021.

Zipin, L., S. Sellar, M. Brennan, and T. Gale. 2015. Educating for futures in marginalized regions: A sociological framework for rethinking and researching aspirations. Educational Philosophy and Theory 47 (3): 227-246. 
Publisher's Note Springer Nature remains neutral with regard to jurisdictional claims in published maps and institutional affiliations.

Astrid Matejcek is a $\mathrm{PhD}$ candidate in Geography at the Rheinische Friedrich-Wilhelms University in Bonn, Germany. She is also a Junior Researcher in the Collaborative Research Centre "Future Rural Africa" funded by the German Research Council. Her main interest is in human-environment relations, with an empirical focus on rural transformation processes in conservation and agriculture in Eastern Africa.

Julia Verne is a Professor of Cultural Geography at the Johannes Gutenberg University in Mainz, Germany. Her current focus is on ethnographic research in Eastern Africa and the Indian Ocean World with a specific interest in mobilities and human-technology-nature relations. 